\title{
Studi Pengaruh Suhu dan Lama Penggorengan Terhadap Kualitas Jamur Tiram (Pleurotus osteatus) dengan Penggorengan Vacum
}

\author{
Study of the Effect of Temperature and Frying Time on the Quality of Oyster Mushroom \\ (Pleurotus osteatus) Using Vacuum Frying
}

\section{St. Sabahannur, Suraedah Alimuddin, Hanifa Nikmah}

\author{
Program Studi Agroteknologi Fakultas Pertanian Universitas Muslim Indonesia, Jl. Urip Sumoharjo, km. 5. \\ Makassar, Indonesia \\ Penulis korespondensi: St. Sabahannur, email: stsabahannur@umi.ac.id
}

Tanggal submisi: 23 Juli 2021; Tanggal penerimaan: 25 Oktober 2021; Tanggal publikasi: 9 November 2021

\begin{abstract}
Oyster mushroom is one type of vegetable that is rarely utilized due to a lack of knowledge about how to process the mushroom itself. The perishable nature of mushrooms causes difficulties in distribution and marketing as fresh produce. One of the processed products from oyster mushrooms is chips. Vacuum frying is a frying method that is applied to heat-sensitive materials such as fruits and vegetables. This study was aimed to determine the effect of temperature and duration of vacuum frying on the physicochemical and organoleptic qualities of oyster mushroom chips. The study was conducted using a completely randomized design with a two-factor factorial pattern: the first factor, vacuum frying with a temperature of $85^{\circ}$ and $90^{\circ} \mathrm{C}$. The second factor, frying time, is 50,60, and 70 minutes. The results showed that vacuumfried oyster mushrooms with a temperature of $85^{\circ} \mathrm{C}$ and a frying time of 70 minutes produced oyster mushroom chips with the lowest fat content of $38.08 \%$, the preferred taste, and color (score 4), while the preferred texture was frying at $90^{\circ} \mathrm{C}$ and long 70 minutes. The yield value and moisture content of oyster mushroom chips did not differ at different temperatures and frying times.
\end{abstract}

Keywords: Chips; Oyster mushroom; temperature; vacuum frying

(C) The Authors. Publisher Universitas Pattimura. Open access under CC-BY-SA license.

\begin{abstract}
ABSTRAK
Jamur tiram merupakan salah satu jenis sayuran yang pemanfaatannya sangat sedikit karena kurangnya pengetahuan tentang cara mengolah jamur itu sendiri. Sifat jamur yang mudah rusak menyebabkan kesulitan dalam distribusi dan pemasaran sebagai produk segar. Salah satu produk olahan dari jamur tiram adalah keripik. Penggorengan vakum merupakan metode penggorengan yang diterapkan pada bahan yang peka terhadap panas seperti buah-buahan dan sayuran. Penelitian bertujuan mengetahui pengaruh suhu dan lama waktu penggorengan vakum terhadap kualitas fisikokimia dan organoleptik keripik jamur tiram. Penelitian dilakukan menggunakan rancangan acak lengkap dengan pola faktorial dua faktor. Faktor pertama, penggorengan vakum dengan suhu $85^{\circ}$ dan $90^{\circ} \mathrm{C}$. Faktor kedua, lama penggorengan adalah 50, 60, dan 70 menit. Hasil penelitian menunjukkan jamur tiram yang digoreng vakum dengan suhu $85^{\circ} \mathrm{C}$ dan lama penggorengan 70 menit menghasilkan keripik jamur tiram dengan kadar lemak terendah 38,08\%, rasa, dan warna yang disukai (skor 4), sedangkan tekstur yang disukai adalah penggorengan pada suhu $90^{\circ} \mathrm{C}$ dan lama. 70 menit. Nilai rendemen dan kadar air keripik jamur tiram tidak menunjukkan perbedaan pada suhu dan waktu penggorengan yang berbeda.
\end{abstract}

Kata kunci: Jamur tiram; keripik; penggorengan vakum; suhu

(C) Penulis. Penerbit Universitas Pattimura. Akses terbuka dengan lisensi CC-BY-SA.

\section{PENDAHULUAN}

Pergeseran gaya hidup konsumen, menyebabkan makanan yang memiliki makro- dan mikronutrien dan sifat antioksidan tinggi menjadi populer saat ini. Jamur tiram adalah salah satu komoditas yang mengandung nutrisi dalam jumlah tinggi dan sifat antioksidan sekarang mendapat perhatian (Hilapad et al., 2020). Jamur tiram mengandung air, serat, zat besi, kalsium, vitamin B1, vitamin B2, dan 
vitamin $\mathrm{C}$, kandungan protein tinggi, kaya vitamin dan mineral, rendah karbohidrat, lemak, dan kalori. Komposisi dan kandungan nutrisi setiap $100 \mathrm{~g}$ jamur tiram adalah 367 kalori, 10,5-30,4\% protein, $64,1 \%$ karbohidrat, 2,66\% lemak, 0,20 mg thiamin, 4,7-4,9 $\mathrm{mg}$ riboflavin, 77,2 $\mathrm{mg}$ niacin, dan 314,0 $\mathrm{mg}$ kalsium. Kalori yang terkandung dalam jamur tiram adalah $100 \mathrm{~kJ} / 100 \mathrm{~g}$ dengan $72 \%$ lemak takjenuh karena kandungan lemaknya rendah sehingga cocok untuk dikonsumsi oleh para pelaku diet, serat jamur sangat cocok untuk pencernaan (Sumarsih, 2015).

Popularitas jamur sebagai pangan fungsional meningkatkan permintaan dan konsumsinya. Namun, sifat jamur yang mudah rusak menyebabkan kesulitan dalam distribusi dan pemasaran sebagai produk segar (Li et al., 2013). Mengingat sifat jamur tiram yang sangat mudah rusak, diperlukan teknik pemrosesan yang tepat dan sesuai yang dapat memperpanjang umur simpan tanpa mengurangi nutrisi dan sifat fitokimia komoditas tersebut adalah merupakan sebuah tantangan. Untuk meningkatkan nilai ekonominya perlu diusahakan berbagai macam produk olahan yang nantinya akan memberi nilai tambah. Salah satu produk olahan dari jamur tiram yang dapat diusahakan yaitu keripik jamur tiram. Diketahui bahwa produk yang digoreng memiliki daya tarik bagi konsumen untuk semua kelompok umur dan hampir semua budaya, prosesnya cepat dan mudah dibuat terus menerus untuk produksi massal, dan makanan tampak steril dan kering, dengan umur simpan yang relatif lama (Hilapad et al., 2020).

Di antara semua metode pemrosesan yang tersedia, penggorengan vakum menjadi salah satu solusi yang paling layak untuk masalah ini. Penggorengan vakum adalah teknik menggoreng makanan dalam minyak dengan tekanan di bawah tingkat atmosfer, yang berfungsi untuk mengurangi kandungan minyak, mengurangi perubahan warna, kehilangan vitamin dan senyawa lain yang biasanya terkait dengan oksidasi dan pemrosesan suhu tinggi (Diamante et al., 2015).

Metode ini merupakan alternatif untuk menghasilkan produk goreng yang berkualitas tinggi dengan suhu penggorengan yang lebih rendah. Penggorengan pada suhu dan tekanan rendah mengurangi jumlah minyak yang menembus ke dalam material dan kerusakan oleh oksidasi minyak goreng sehingga mengakibatkan produk gorengan yang stabil (Sothornvit, 2011). Dibandingkan dengan teknologi dehidrasi lainnya untuk buah-buahan dan sayuran, penggorengan vakum adalah pilihan yang layak untuk memperoleh produk kering berkualitas tinggi dalam pemrosesan yang waktunya lebih singkat (Tarzi et al., 2011).

Berkembangnya teknologi penggorengan vakum berpeluang menghasilkan keripik jamur yang memiliki rasa dan aroma seperti bahan aslinya, tekstur renyah, serta nilai gizinya relatif dapat dipertahankan karena suhu peng-gorengan relatif rendah. Penggorengan vakum adalah salah satu metode opsional terbaru yang diterapkan pada bahan yang sensitif panas seperti buah-buahan dan sayuran dengan kandungan minyak rendah dan tekstur yang diinginkan dan karakteristik yang disukai, di bawah tekanan rendah, sebaiknya lebih rendah dari 6,65 $\mathrm{kPa}$ (Moreira, 2014), titik didih air menurun di bawah $100^{\circ} \mathrm{C}$ sehingga suhu tinggi tidak diperlukan untuk penggorengan. Penggorengan vakum pada suhu yang lebih rendah membantu mempertahankan warna, rasa, aroma dan kualitas gizi (Ayustaningwarno et al., 2020; Dueik et al., 2010; Wanakamol \& Poonlarp, 2018). Selain itu, penggorengan vakum adalah teknik yang menjanjikan untuk makanan gorengan yang lebih sehat dengan banyak keuntungan termasuk mengurangi penyerapan minyak, menjaga warna dan rasa alami, mempertahankan lebih banyak vitamin dan mineral serta mengurangi pembentukan racun karsinogenik misalnya akrilamida dan furan (Dueik \& Bouchon, 2011; Moreira, 2014). Teknologi penggorengan vakum dilaporkan telah menghasilkan keripik kentang, pisang, wortel, apel, dan buah kiwi (Belkova et al., 2018; Diamante et al., 2012; Sothornvit, 2011).

Penelitian Wanakamol dan Poonlarp (2018) menunjukkan suhu penggorengan $90^{\circ}$ dan $95^{\circ} \mathrm{C}$, dengan waktu penggorengan 50 dan 60 menit, berpengaruh signifikan terhadap kadar air keripik nanas goreng vakum. Asmawit dan Hidayati (2014), melaporkan bahwa suhu penggorengan vacum antara $85^{\circ}-90^{\circ} \mathrm{C}$ dan irisan setebal $3 \mathrm{~mm}$ merupakan kombinasi yang baik dalam pembuatan keripik nanas dan memenuhi SNI 01-4304-1996.

Penelitian Suryanti (2010), mengenai pengolahan jamur tiram dengan konsentrasi garam dan gula $1 \%$ dan $5 \%$, menunjukkan bahwa uji organoleptik terhadap warna, kerenyahan, bentuk dan rasa jamur tiram diterima dengan baik, sedangkan penelitian mengenai pengaruh suhu dan waktu penggorengan pada jamur tiram belum dilakukan. Penelitian ini bertujuan untuk mengetahui efek suhu dan waktu penggorengan terhadap sifat fisikokimia (rendemen, kadar air, kadar lemak, rasa, warna dan tekstur) dari keripik jamur tiram goreng vakum. 


\section{METODE PENELITIAN}

\section{Bahan}

Bahan penelitian utama yang digunakan dalam penelitian, yakni jamur tiram putih yang diperoleh dari Balai Besar Pelatihan Pertanian Kabupaten Gowa, Sulawesi Selatan.

\section{Pelaksanaan Penelitian}

Proses penelitian dimulai dari pemisahan tangkai jamur tiram, lalu dibersihkan dengan air, kemudian ditiriskan sekitar 5-10 menit. Proses selanjutnya penggorengan dengan vacuum frying (Lastrindo Engineering, Indonesia) dengan suhu $85^{\circ}$ dan $90^{\circ} \mathrm{C}$ dan lama penggorengan 50,60 , dan 70 menit. Minyak goreng yang digunakan adalah Bimoli (Indonesia) sebanyak 13 L. Keripik jamur tiram ditiriskan dengan mesin spinner (Lastrindo Engineering, Indonesia). Keripik jamur tiram dikemas dengan plastik polypropilen (PP).

\section{Rendemen}

Rendemen merupakan persentase berat dari produk akhir yang dihasilkan per berat dari bahan olahan. Rendemen dihitung mengikuti metode yang dikemuakan oleh Lastriyanto et al. (2019), dengan rumus:

$\%$ Rendemen $=\frac{\text { Berat hasil olahan }}{\text { Berat olahan }} \times 100 \%$

\section{Kadar Air}

Kadar air sampel dianalisis berdasarkan metode AOAC (2000). Sampel sebanyak $5 \mathrm{~g}$ dimasukkan ke dalam cawan. Cawan dimasukkan ke oven (Memmert, Jerman) dengan suhu $105^{\circ} \mathrm{C}$ selama 6 jam dan ditimbang ulang sebanyak dua kali.

Kadar Air $(\%)=\frac{\text { Berat awal bahan-Berat akhir bahan }}{\text { Berat sampel }} \times 100 \%$

\section{Kadar Lemak}

Analisa kadar lemak dilakukan dengan metode Soxhlet (AOAC, 2000). Labu lemak dikeringkan dalam oven (Memmert, Jerman). Sampel ditimbang sebanyak 5 g dibungkus dengan kertas saring dan ditutup kapas bebas lemak. Kertas saring berisi sampel tersebut diletakkan dalam alat ekstraksi Soxhlet yang dirangkai dengan konden- sor. Pelarut heksana (Merck, Jerman) dimasukkan kedalam labu lemak, selanjutnya direfluks selama minimal 5 jam. Sisa pelarut dalam labu lemak dihilangkan dengan dipanaskan dalam oven dengan suhu $105^{\circ} \mathrm{C}$, selanjutnya ditimbang.

Kadar lemak dihitung dengan rumus:

Kadar lemak $(\%)=\frac{\text { berat lemak }}{\text { berat } \operatorname{sampel}(g)} \times 100 \%$

\section{Uji Organoleptik Warna, Tekstur dan Rasa}

Uji organoleptik meliputi warna tekstur dan rasa mengikuti metode yang dikemukakan oleh Ayustaningwarno (2014). Metode yang dipakai dalam pengujian adalah uji kesukaan (hedonik) keripik jamur tiram terhadap 20 panelis tidak terlatih. Uji organoleptik menggunakan skala sebagai berikut: Sangat tidak suka (1), tidak suka (2), agak suka (3), suka (4), sangat suka (5). Perhitungan uji organoleptik dengan menggunakan metode skala Likert.

\section{Analisis Statistik}

Penelitian dilaksanakan dengan menggunakan rancangan acak lengkap pola faktorial. Faktor pertama adalah suhu penggorengan yang terdiri atas dua taraf yaitu $85^{\circ} \mathrm{C}(\mathrm{S} 1)$ dan $90^{\circ} \mathrm{C}(\mathrm{S} 2)$. Faktor kedua lama penggorengan yakni, 50 menit (L1), 60 menit (L2) dan 70 menit (L3). Setiap perlakuan diulang sebanyak tiga kali, sehingga terdapat 18 unit percobaan. Data yang diperoleh di uji dengan analisis keragaman dengan taraf kepercayaan 95\% menggunakan program SPSS versi 16. Pengujian beda antara rataan perlakuan menggunakan uji BNT $(\alpha=0,05)$.

\section{HASIL DAN PEMBAHASAN}

\section{Rendemen}

Hasil pengamatan rendemen keripik jamur tiram menunjukkan bahwa suhu dan lama penggorengan serta interaksinya tidak berpengaruh nyata terhadap rendemen keripik jamur tiram. Ratarata rendemen keripik jamur tiram dapat dilihat pada Gambar 1.

Gambar 1 menunjukkan bahwa suhu $90^{\circ} \mathrm{C}$ dengan lama penggorengan 60 menit (S2L2) menghasilkan rendemen cenderung lebih tinggi, yaitu $21,29 \%$, sedangkan rendemen terendah diperoleh pada kombinasi suhu $85^{\circ} \mathrm{C}$ dengan lama 
penggorengan 70 menit (S1L3) yakni 17,63\%. Nilai rendemen yang diperoleh pada penelitian ini lebih tinggi dibandingkan hasil penelitian yang dilaporakan oleh Sumarlan et al. (2016), bahwa keripik jamur tiram putih dengan perlakuan rendaman $\mathrm{CaCl}_{2}$ 0,01\% selama 0, 30 dan 45 menit berkisar antara 9,30-10,80\%. Nilai rendaman untuk keripik jamur kancing dengan perlakuan rendaman $\mathrm{CaCl}_{2}$ 0,01\% selama 0, 30 dan 45 menit berkisar antara 8,7-11,94\%.

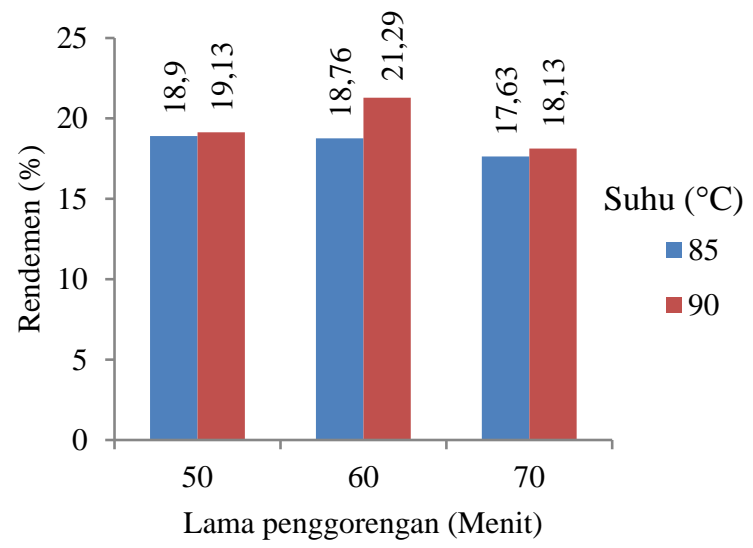

Gambar 1. Rendemen keripik jamur tiram pada suhu dan lama penggorengan berbeda

\section{Kadar Air}

Hasil pengamatan kadar air pada keripik jamur tiram dan sidik ragamnya menunjukkan bahwa suhu dan lama penggorengan serta interaksinya tidak berpengaruh nyata terhadap kadar air keripik jamur tiram. Rata-rata kadar air keripik jamur tiram dapat dilihat pada Gambar 2.

Gambar 2 menunjukkan bahwa suhu $90^{\circ} \mathrm{C}$ dengan lama penggorengan 50 menit (S2L1) menghasilkan kadar air cenderung lebih rendah, yakni $6,324 \%$, sedangkan kadar air yang tinggi diperoleh pada kombinasi suhu $85^{\circ} \mathrm{C}$ dengan lama penggorengan 60 menit (S1L2) yaitu 12,394\%. Penggunaan suhu penggorengan yang makin meningkat menyebabkan makin besar air yang menguap, sehingga air yang terkandung dalam keripik buah akan berkurang (Tumbel \& Manurung, 2017).

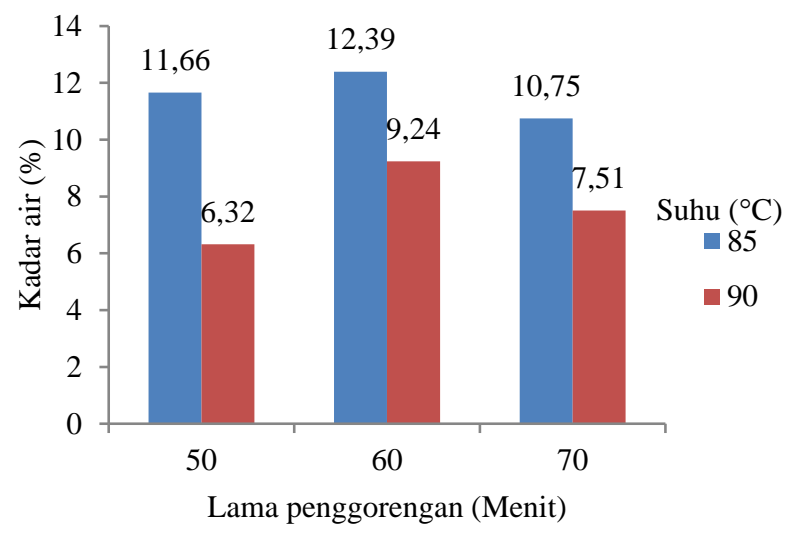

Gambar 2. Kadar air keripik jamur tiram pada suhu dan lama penggorengan berbeda

\section{Kadar Lemak}

Hasil pengamatan rata-rata kadar lemak keripik jamur tiram dan sidik ragamnya nenunjukkan bahwa suhu dan lama penggorengan serta interaksi berpengaruh sangat nyata $(P<0,01)$ terhadap kadar lemak keripik jamur tiram. Rata-rata kadar lemak keripik jamur tiram dapat dilihat pada Tabel 1.

Berdasarkan uji BNT 5\% (Tabel 1) bahwa suhu $85^{\circ} \mathrm{C}$ dengan lama penggorengan 70 menit menghasilkan kadar lemak terendah 38,08\% (S1L3) dan berbeda nyata dengan suhu $85^{\circ} \mathrm{C}$ dan lama penggorengan 60 menit (S1L2) dan suhu $85^{\circ} \mathrm{C}$ dengan lama penggorengan 50 menit (S1L1). Penyerapan minyak diketahui berkaitan dengan hilangnya kadar air dari keripik.

Perlakuan suhu $85^{\circ} \mathrm{C}$ dengan lama penggorengan 50 menit menghasilkan kadar lemak $40,24 \%$ dan berbeda nyata dengan suhu $90^{\circ} \mathrm{C}$ dengan lama penggorengan 50 menit (S2L1).

Tabel 1. Persentasi Kadar Lemak keripik jamur tiram dengan kombinasi suhu dan lama penggorengan

\begin{tabular}{|c|c|c|c|c|c|}
\hline \multirow{3}{*}{$\begin{array}{c}\text { Suhu } \\
\text { penggorengan } \\
\left({ }^{\circ} \mathrm{C}\right) \\
\end{array}$} & \multicolumn{4}{|c|}{ Lama Penggorengan (menit) } & \multirow{3}{*}{ NP BNT } \\
\hline & 50 & 60 & 70 & \multirow{2}{*}{ Rata-rata } & \\
\hline & \multicolumn{3}{|c|}{$\%$} & & \\
\hline 85 & $40,24 \frac{b}{y}$ & $46,17 \frac{a}{x}$ & $38,08 \frac{c}{y}$ & 41,49 & 1,64 \\
\hline 90 & $42,78 \frac{b}{x}$ & $46,71 \frac{a}{x}$ & $45,08 \frac{a}{x}$ & 44,85 & \\
\hline Rata-rata & 41,51 & 46,88 & 41,58 & & \\
\hline
\end{tabular}

Keterangan: Angka yang diikuti huruf berbeda pada baris $(\mathrm{a}, \mathrm{b}, \mathrm{c})$ dan kolom $(\mathrm{x}, \mathrm{y})$ berbeda nyata pada taraf $\mathrm{a}=0,05$. 
Suhu $85^{\circ} \mathrm{C}$ dengan lama penggorengan 60 menit menghasilkan kadar lemak $46,17 \%$, tetapi tidak berbeda nyata dengan suhu $90^{\circ} \mathrm{C}$ dengan lama penggorengan 60 menit (S2L2). Hal ini berbeda dengan hasil penelitian Ismed (2016), bahwa penggorengan vakum dengan suhu $85^{\circ} \mathrm{C}$ dengan lama penggorengan 60 menit menghasilkan keripik wortel dengan kadar lemak 20,54\%, sedangkan kadar lemak terendah pada suhu $90^{\circ} \mathrm{C}$ dengan waktu 70 menit. Muhammadali et al. (2021) melaporkan, kadar asam lemak bebas keripik salak terendah, yaitu pada perlakuan suhu $80^{\circ} \mathrm{C}$ dengan lama penggorengan 30 menit.

Menurut Maitey et al. (2014), peningkatan suhu dan waktu penggorengan vakum mengakibatkan peningkatan kandungan minyak. Suhu penggorengan yang tinggi pada penggorengan keripik dapat menyebabkan dehidrasi yang lebih banyak pada permukaan bahan sehingga menye-babkan penetrasi minyak ke dalam bahan menjadi lebih banyak. Pada saat proses penggorengan, minyak memasuki kerak dan mengisi ruang yang semula berisi air. Proses penyerapan minyak terjadi ketika massa minyak perlahan-lahan masuk ke dalam bahan yang digoreng dan makin mening-katnya suhu maka minyak/lemak makin meningkat seiring dengan penurunan tekanan vakum. Massa minyak masuk ke bahan yang digoreng secara difusi karena adanya perbedaan konsentrasi massa minyak di permukaan dengan bagian dalam bahan. Proses penyerapan minyak pada bahan terjadi lebih cepat ketika penurunan kadar air bahan lebih rendah (Tumbel dan Manurung, 2017).

\section{Rasa}

Uji organoleptik terhadap rasa keripik jamur tiram dilakukan terhadap 20 orang panelis. Uji kesukaan meliputi kriteria: 1 = Tidak suka, 2 = Agak suka, 3 = cukup, 4 = suka, 5 = sangat suka. Hasil pengamatan disajikan pada Gambar 3.

Pada Gambar 3. Uji kesukaan terhadap rasa menunjukkan bahwa 69\% panelis suka (skor 4) keripik jamur yang digoreng pada suhu $85^{\circ} \mathrm{C}$ dengan lama penggorengan 70 menit (S1L3), kemudian keripik jamur tiram yang digoreng dengan suhu $90^{\circ} \mathrm{C}$ selama 70 menit (S2L3) dengan skor 4 (Suka). Sedangkan keripik jamur tiram yang digoreng dengan suhu $85^{\circ}$ dan $90^{\circ} \mathrm{C}$ dengan lama penggorengan 60 menit $48 \%$ cukup suka (skor 3 ). Hasil penelitian Afrozi et al. (2018), pada produk keripik pisang kepok menunjukkan bahwa penerimaan panelis tertinggi untuk rasa terdapat pada perlakuan suhu $90^{\circ} \mathrm{C}$ dengan waktu penggorengan 50 menit, sedangkan yang terendah terdapat pada perlakuan suhu $70^{\circ} \mathrm{C}$ dengan waktu penggorengan 30 menit. Makin tinggi suhu dan waktu penggorengan, maka penilaian panelis untuk rasa keripik makin tinggi.

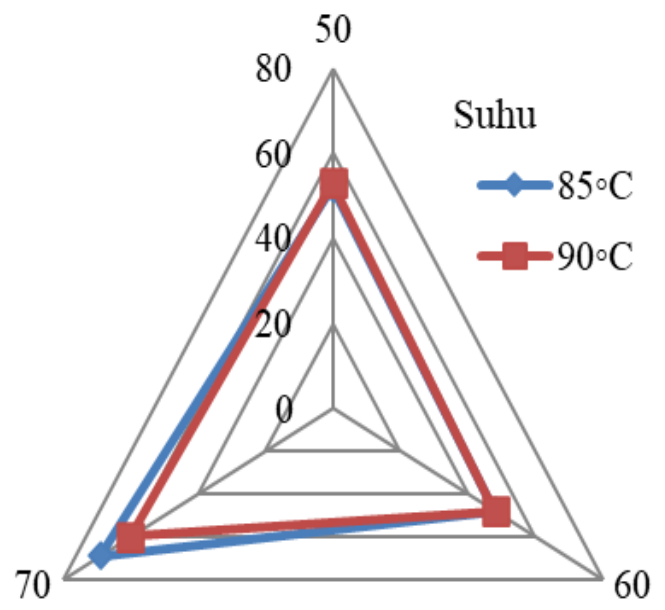

Gambar 3. Diagram laba laba tingkat kesukaan rasa jamur tiram

\section{Warna}

Pengamatan terhadap warna keripik jamur tiram dilakukan secara hedonik oleh 20 orang panelis tidak terlatih, yang diminta untuk menilai warna keripik jamur tiram hasil penggorengan vakum nilai rata-rata penilaian panelis dapat dilihat pada Gambar 4.

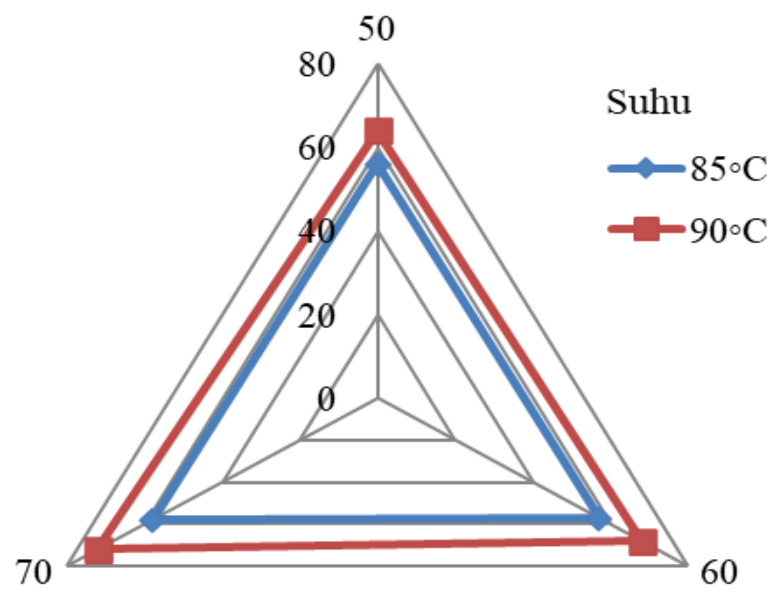

Gambar 4. Diagram laba laba kesukaan warna keripik jamur tiram

Gambar 4, menunjukkan bahwa $72 \%$ panelis suka (skor 4) pada keripik jamur tiram yang digoreng pada suhu $90^{\circ} \mathrm{C}$ dengan lama penggorengan 70 menit (S2L3). Sedangkan keripik 
jamur tiram yang digoreng dengan suhu $90^{\circ} \mathrm{C}$ dengan lama penggorengan 60 menit (S2L2) yaitu $68 \%$ suka (skor 4) dan $57 \%$ cukup suka (skor 3 ) keripik jamur tiram yang digoreng pada suhu $85^{\circ} \mathrm{C}$ dengan lama penggorengan 60 menit (S1L2). Menurut Ketaren (2005), lapisan luar permukaan akan berwarna cokelat keemasan akibat penggorengan. Adanya warna pada permukaan bahan disebabkan oleh reaksi browning atau reaksi Maillard. Intensitas warna tergantung dari suhu dan lama penggorengan, juga komposisi kimia yang terdapat pada permukaan luar dari bahan pangan (Pakpahan et al., 2014).

\section{Tekstur}

Tekstur merupakan atribut kualitas yang penting dalam menentukan daya terima produk gorengan karena tekstur produk gorengan yang dihasilkan tergantung pada sifat bahan baku seperti kadar pati, ukuran granula pati, polisakarida dinding sel, polisakarida nonpati, pektin, dan kondisi pemrosesan yang meliputi waktu dan suhu penggorengan (Nourian dan Ramaswamy, 2003). Kekerasan adalah parameter tekstur utama dan tergantung pada perubahan fisik dan kimia seperti pelepasan bahan intraseluler, gelatinisasi pati, dehidrasi, pembentukan kerak, pemecahan kekuatan perekat antarsel, penguapan air, dan ekspansi jaringan (Pedreschi dan Moyano, 2005). Uji organoleptik terhadap tekstur keripik jamur tiram disajikan pada Gambar 5.

Pada Gambar 5, menunjukkan bahwa 77\% panelis suka (skor 4) pada keripik jamur tiram yang digoreng vacum pada suhu $90^{\circ} \mathrm{C}$ dengan lama penggorengan 70 menit (S2L3), sedangkan keripik jamur tiram yang digoreng pada suhu $85^{\circ} \mathrm{C}$ dengan lama penggorengan 70 menit (S1L3) yakni 75\% suka (skor 4) dan suhu $85^{\circ} \mathrm{C}$ dengan lama penggorengan 60 menit (S2L2) yakni 72\% suka (skor 4). Makin banyak air yang teruapkan, maka makin besar rongga atau ruang kosong yang dapat terisi oleh minyak sebagai media penggoreng. Menurut Suprana (2012) makin lama penggorengan maka kadar air yang terkandung dalam keripik buah makin berkurang dan keripik yang dihasilkan makin renyah. Pada pembuatan keripik nanas pembentukan jaringan-jaringan kalsium pektat akan membantu meningkatkan porositas setelah air dalam bahan hilang selama proses penggorengan sehingga meningkatkan kerenyahannya (Tumbel dan Manurung, 2017)

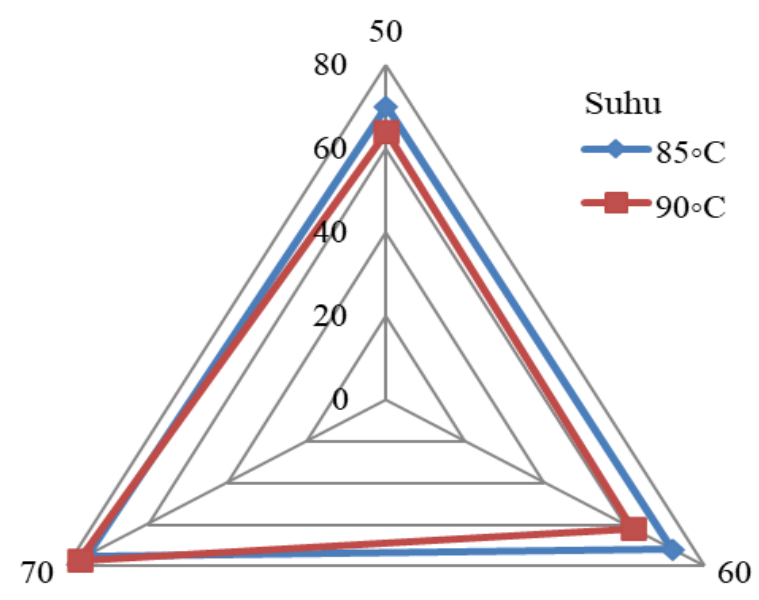

Gambar 5. Diagram laba laba kesukaan tekstur keripik jamur tiram

Penggorengan vakum adalah teknologi penggorengan yang dilakukan di bawah tingkat tekanan di bawah atmosfer (Pandey dan Moreira, 2012). Pemanfaatan penggorengan vakum memberikan panas yang lebih baik dan kecepatan perpindahan massa. Metode ini dilaporkan berhasil diterapkan untuk membuat keripik buah dan mempertahankan rasa dan aroma alaminya, serta menghasilkan tekstur renyah yang baik (Hu et al., 2019). Kerenyahan merupakan atribut tekstur yang menentukan kualitas keripik. Kerenyahan pada irisan nangka ditemukan meningkat dengan kenaikan suhu dan waktu penggorengan. Suhu penggorengan yang lebih tinggi menghasilkan kerenyahan lebih cepat dibandingkan dengan suhu penggorengan yang lebih rendah (Maity et al., 2014).

\section{KESIMPULAN}

Berdasarkan hasil penelitian yang diperoleh bahwa penggorengan vakum dengan suhu dan lama penggorengan berbeda berpengaruh terhadap sifat fisikokimia keripik jamur tiram. Penggorengan dengan suhu $85^{\circ} \mathrm{C}$ dan lama penggorengan 70 menit (S1L3) menghasilkan keripik jamur tiram dengan kadar lemak yang paling rendah 38,08\% dengan rasa dan warna yang disukai (skor 4), sedangkan tekstur keripik jamur tiram yang disukai pada penggorengan pada suhu $90^{\circ} \mathrm{C}$ dengan lama penggorengan 70 menit (S2L3). Nilai rendemen dan kadar air keripik jamur tiram tidak menunjukkan perbedaan pada suhu $85^{\circ} \mathrm{C}$ dan $90^{\circ} \mathrm{C}$ dan lama penggorengan 50, 60 dan 70 menit. 


\section{DAFTAR PUSTAKA}

[AOAC] Association of Official Analytical Chemists. 2000. Official Methods of Analysis of AOAC International. Eds. 17. Association of Official Analytical Chemists, Maryland (US).

Afrozi, S., Mufarida, N.A., \& Sofiyah, R. (2018). Hubungan optimalisasi suhu dan waktu penggorengan pada mesin vacuum frying terhadap peningkatan kualitas keripik pisang kapok. Jurnal Proteksion, 2(2), 43-52. https://doi.org/10.32528/jp.v2i2.2229

Asmawit, \& Hidayati. (2014). Pengaruh suhu penggorengan dan ketebalan irisan buah terhadap karakteristik keripik nanas menggunakan penggorengan vakum. Jurnal Litbang Industri, 4(2), 115-121. http:// dx.doi.org/10.24960/jli.v4i2

Ayustaningwarno, F. (2014). Teknologi Pangan. Yogyakarta: Graha Ilmu.

Ayustaningwarno, F., van Ginkel, E., Vitorino, J., Dekker, M., Fogliano, V., \& Verkerk, R. (2020). Nutritional and physicochemical quality of vacuum-fried mango chips is affected by ripening stage, frying temperature, and time. Frontiers in Nutrition, 7, 95. https://doi.org/10.3389/fnut.2020.00095

Belkova, B., Hradecky, J., Hurkova, K., Forstova, V., Vaclavik, L., \& Hajslova, J. (2018). Impact of vacuum frying on quality of potato crisps and frying oil. Food Chemistry, 241, 51-59.

https://doi.org/10.1016/j.foodchem.2017.08. 062

Diamante, L.M., Savage, G.P., \& Vanhanen, L.P. (2012). Optimisation of vacuum frying of gold kiwifruit slices: Application of response surface methodology. International Journal of Food Science \& Technology, 47(3), 518524. $\quad$ https://doi.org/10.1111/j.13652621.2011.02872.x

Diamante, L.M., Shi, S., Hellmann, A., \& Busch, J. (2015). Vacuum frying foods: Products, process and optimization. International Food Research Journal, 22(1), 15-22.

Dueik, V., Robert, P. \& Bouchon, P. (2010). Vacuum frying reduces oil uptake and improves the quality parameters of carrot crisps. Food Chemistry, 119(3), 1143-1149. https://doi.org/10.1016/j.foodchem.2009.08. 027
Dueik, V. \& Bouchon, P. (2011). Development of healthy low-fat snacks: Understanding the mechanisms of quality changes during atmospheric and vacuum frying. Food Reviews International, 27(4), 408-432. https://doi.org/10.1080/87559129.2011.5636 38

Hilapad, M.R., Esguerra, E.B., \& Castillo-Israel, K.A.T. (2020). Optimization of processing parameters for vacuum fried oyster mushroom (Pleurotus ostreatus (Jacquin) P. Kummer). Food Research, 4(4), 1371-1382. https://doi.org/10.26656/fr.2017.4(4).065

Hu, J., Zeng, H., Deng, C., Wang, P., Fan, L., Zheng, B., \& Zhang, Y. (2019). Optimization of vacuum frying condition for producing silver carp surimi chips. Food science \& nutrition, 7(8), https://doi.org/10.1002/fsn3.1077

Ismed. (2016). Analisis proksimat keripik wortel (Daucus carota L.) pada suhu dan lama penggorengan yang berbeda menggunakan mesin vacuum frying. Jurnal Teknologi Pertanian Andalas, 20(2), 25-32. https://doi.org/10.25077/jtpa.20.2.2532.2016

Ketaren, S. (2005). Pengantar Teknologi Minyak dan Lemak Pangan. Jakarta: UI-Press.

Lastriyanto, A., Argo, B.D., \& Pratiwi, R.A. (2019). Karakteristik fisik dan protein fillet daging ikan lele beku (Clarias batrachus) hasil penggorengan vakum. Jurnal Keteknikan Pertanian Tropis dan Biosistem, 7, 87-96.

Li, P., Zhang, X., Hu, H., Sun, Y., Wang, Y., \& Zhao, Y. (2013). High carbon dioxide and low oxygen storage effects on reactive oxygen species metabolism in Pleurotus eryngii. Postharvest Biology and Technology, $\quad 85, \quad 141-146$. https://doi.org/10.1016/j.postharvbio.2013.0 5.006

Maity, T., Bawa A.S., \& Raju, P.S. (2014). Effect of vacuum frying on changes in quality attributes of jackfruit (Artocarpus heterophyllus) bulb slices. International Journal of Food Science, 752047. https://doi.org/10.1155/2014/752047

Moreira, R.G. (2014). Vacuum frying versus conventional frying - An overview. European Journal of Lipid Science and Technology, 116, 723-734. https://doi.org/10.1002/ejlt.201300272

Muhammadali, A., Jamaluddin, \& Fadilah, R. (2021). Kualitas keripik salak (Salacca 
zalacca) pada berbagai variasi temperatur dan waktu selama penggorengan hampa udara. Jurnal Pendidikan Teknologi Pertanian, 7, 67-78.

Nourian, F. \& Ramaswamy, H.S. (2003). Kinetics of quality change during cooking and frying of potatoes: Part I. Texture. Journal of Food Process Engineering, 26(4), 377-394. https://doi.org/10.1111/j.17454530.2003.tb00608.x

Pakpahan, Y.E., Lubis, Z., \& Setyohadi. (2014). Pengaruh lama perebusan dan lama penyangraian dengan kuali tanah liat terhadap mutu keripik biji durian (Durio zibethinus Murr). Journal Rekayasa Pangan dan Pertanian, 2(3), 47-53.

Pandey, A. \& Moreira, R.G. (2012). Batch vacuum frying system analysis for potato chips. Journal of Food Process Engineering, 35(6), 863-873. https://doi.org/10.1111/j.17454530.2011.00635.x

Pedreschi, F. \& Moyano. P. (2005). Effect of predrying on texture and oil uptake of potato chips. LWT - Food Science and Technology, 38(6), 599-604. https://doi.org/10.1016/j.lwt.2004.08.008

Sothornvit, R. (2011). Edible coating and postfrying centrifuge step effect on quality of vacuum-fried banana chips. Journal of Food Engineering, 107(3-4): 319-325.
Terakreditasi RISTEKDIKTI Peringkat SINTA 3, SK. 200/M/KPT/2020

https://doi.org/10.1016/j.jfoodeng.2011.07.0 10

Sumarlan, H.S., Lastriyanto, A., \& Erawati, D. (2016). Karakteristik penggorengan vakum jamur. Kajian jamur tiram putih (Pleurotus ostreatus) dan jamur kancing (Agaricus bisporus). Jurnal Keteknikan Pertanian Tropis dan Biosistem, 4(2), 148-156.

Sumarsih, S.M. (2015). Oyster Mushroom Seed Business. Jakarta: Penebar Swadaya.

Suprana, Y.A. (2012). Pembuatan keripik pepaya menggunakan metode penggorengan vakuum dengan variabel suhu dan waktu. Tugas Akhir Fakultas Teknik, UNDIP, Semarang.

Tumbel, N., \& Manurung, S. (2017). Pengaruh suhu dan waktu penggorengan terhadap mutu keripik nanas menggunakan penggoreng vakum. Jurnal Penelitian Teknologi Industri, 9(1), 9-22. http://dx.doi.org/10.33749/jpti.v9i1.3204

Tarzi, B.G., Bassiri, A., Ghavami, M. \& Bamenimoghadam, M. (2011). Process optimization in vacuum frying of mushroom using response surface methodology. World Applied Sciences Journal, 14(7), 960-966.

Wanakamol, W. \& Poonlarp, P. (2018). Effects of frying temperature, frying time and cycles on physicochemical properties of vacuum fried pineapple chips and shelf-life prediction. International Food Research Journal, 25(6), 2681-2688. 